\title{
EVALUASI SISTEM PENYELENGGARAAN MAKANAN LUNAK DAN ANALISIS SISA MAKANAN LUNAK DI BEBERAPA RUMAH SAKIT DI DKI JAKARTA, TAHUN 2011
}

\author{
Irfanny Anwar, Edith Herianandita, Ida Ruslita \\ Jurusan Gizi Poltekkes Kemenkes Jakarta II \\ fanny_afif@yahoo.com
}

\section{ABSTRAK}

Pelayanan gizi merupakan salah satu fasilitas pelayanan di rumah sakit. Penyelenggaraan makanan lunak bertujuan memberikan terapi diet yang sesuai dengan kondisi pasien untuk mempercepat penyembuhan. Kegiatan tersebut merupakan rangkaian kegiatan yang dimulai dari perencanaan menu hingga evaluasi. Dalam upaya penyelenggaraan makanan lunak di beberapa rumah sakit masih dijumpai keluhan pasien tentang makanan yang disajikan. Tujuan penelitian adalah mengevaluasi sistem penyelenggaraan makanan lunak dan menganalisis persepsi responden terhadap makanan lunak serta alasan menghabiskan atau tidak menghabiskan makanan. Penelitian ini merupakan penelitian crossectional yang dilakukan di RSUD Pasar Rebo, RS Islam Sukapura, RS Persahabatan Jakarta. Populasi merupakan pasien yang mendapat makanan lunak. Sedangkan sampel adalah sebagian populasi yang diambil secara purposive sejumlah 30 orang di setiap rumah sakit. Hasil penelitian menunjukkan sebagian besar responden adalah laki-laki, usia 36-50 tahun, lulusan SMA, tidak bekerja, jenis diet bervariasi, tidak terganggu nafsu makan, mempunyai pengetahuan yang cukup tentang makanan lunak. Sebagian besar responden tidak menghabiskan makanan pokok, lauk nabati dan sayuran. Rata-rata responden menghabiskan lauk hewani, hidangan penutup, dan makanan selingan. Alasan terbanyak responden tidak menghabiskan makanan adalah porsi terlalu banyak, kenyang, malas makan, tidak suka dan rasa kurang enak. Alasan terbanyak responden menghabiskan makanan adalah lapar, porsi cukup, rasa enak, dan ingin cepat sembuh. Responden yang menilai variasi menu, penampilan menu, dan paduan rasa makanan baik rata-rata $30 \%$. Belum semua tahapan dalam sistem penyelenggaraan makanan banyak dilakukan dengan baik. Kesimpulan penelitian sebagian besar makanan lunak yang disajikan belum dapat dihabiskan responden dan sistem penyelenggaraan makanan lunak masih perlu perbaikan pada menu, standar resep, besar porsi, alat saji, hygiene dan sanitasi. Disarankan untuk melakukan perbaikan menu makanan lunak, variasi bahan makanan, besar porsi, perbaikan alat saji, penampilan pramusaji dan konseling gizi.

Kata kunci: evaluasi penyelenggaraan makanan lunak, analisis sisa makanan, rumah sakit

\section{ABSTRACT}

\section{EVALUATION OF FOOD SERVICE SYSTEM AND ANALYSIS OF LEFTOVER FOODS FROM SEVERAL HOSPITALS IN DKI JAKARTA, 2011}

Nutrition service is one of the important hospital services at hospital level. One of the nutrition services is food service, especially soft food service in order to give diet therapy based on clients condition to accelerate the healing process. This activity is a series of process started from menu planning up to evaluation. In food service, in many hospitals soft diet service faces client complaints. The aims of this study is to evaluate the soft diet service system and to analyse left over foods. This study was conducted in Pasar Rebo Hospital, Islam Sukapura Hospital, and Persahabatan Hospital. The population were taken purposively and respondents were limited to 30 persons for each hospital. The result shows that most of the clients were man, 36-50 years old, graduated from senior high school, unemployed, ate a wide range of food, no appetite disturbance, have good knowledge about soft texture diet. In the averange, they consumed animal protein, dessert, and snacks completely. However, majority of clients could not finish staple food completely as well as animal protein, and vegetables. In average, more then $35 \%$ of the clients could not consume their dishes. Reasons for they did not consume all portion were too big portion, feel full, did not have appetide and the foods was undelicious. The clients gave a good mark for menu variation, menu performance and suitable combination of menu the averages were $30 \%$. The stages in food service system had not been implemented well yet. In conclusion, most of served soft texture diet was not entirely consumed and the food service system should be improved especially at menu arrangement, standard of recipe, portion of food, serving utensils, hygiene and sanitation. The recommendations are to improve the menu of soft texture diet, food variation, food portion, improve utensils, waiter performance and nutrition counseling.

Keywords: evaluation of soft-food preparation service, food leftover analysis, hospital 


\section{PENDAHULUAN}

$\mathrm{M}$ erujuk SK Menkes no 134/1978 tentang organisasi dan tata laksana Rumah Sakit Umum dan SK MenKes No 983/1992 tentang Rumah Sakit Swadana dinyatakan bahwa yang menangani kegiatan gizi di rumah sakit adalah instalasi gizi yang merupakan sarana penunjang kegiatan fungsional. ${ }^{1}$ Ruang lingkup kegiatan pokok pelayanan gizi di rumah sakit terdiri dari: Asuhan gizi pasien rawat jalan, asuhan gizi pasien rawat inap, penyelenggaraan makanan serta penelitian dan pengembangan gizi.

Pelayanan gizi yang bermutu di rumah sakit akan membantu mempercepat proses penyembuhan pasien, yang berarti pula memperpendek lama hari rawat sehingga dapat menghemat biaya pengobatan. ${ }^{2}$ Salah satunya adalah pelayanan makanan, yang bertujuan memberikan makanan dengan mempertimbangkan kebutuhan gizi dan citarasa makanan.

Standar makanan umum rumah sakit terdiri dari makanan biasa, makanan lunak, makanan saring dan makanan cair. $^{3}$ Dalam upaya penyelenggaraan makanan termasuk makanan lunak pada kenyataannya masih dijumpai keluhan pasien tentang makanan yang disajikan. Dari hasil penelitian daya terima makanan lunak pada pasien kelas III yang dilakukan oleh instalasi gizi RSUP Persahabatan pada tahun 2010 menunjukkan 35 persen dari 100 orang tidak dapat menghabiskan makanannya, dengan rata-rata sisa makanan sebanyak 40 persen. ${ }^{4}$ Penelitian Harvie (2011) menunjukkan sisa makanan pokok lebih dari 20 persen pada setiap waktu makan. ${ }^{5}$ Merujuk dari hasil penelitian tersebut peneliti ingin melakukan evaluasi sistem penyelenggaraan makanan lunak serta analisis persepsi pasien terhadap makanan lunak di beberapa rumah sakit di Jakarta. Dalam penelitian ini peneliti memilih tempat penelitian di rumah sakit pemerintah dan rumah sakit swasta. Penelitian bertujuan melakukan evaluasi sistem penyelenggaraan makanan lunak dan menganalisis sisa makanan lunak di beberapa rumah sakit di DKI Jakarta yaitu RSUD Pasar Rebo, RS Islam Sukapura, RS Persahabatan Jakarta.

\section{METODE PENELITIAN}

Penelitian ini merupakan penelitian survey, populasi adalah seluruh pasien yang mendapat makanan lunak di rumah sakit lokasi penelitian, sampel adalah bagian dari populasi yang diambil secara purposive sejumlah 30 orang di setiap rumah sakit, dengan kriteria sampel pasien dewasa (21-60 tahun), mendapat makanan lunak, minimal sudah dirawat selama dua hari, bisa berkomunikasi, bersedia mengikuti penelitian. Data primer didapatkan melalui wawancara dengan menggunakan kuesioner dan observasi. Data dianalisis secara univariat dan tabulasi silang dengan pengelompokan pada variabel-variabel yang ada.

\section{HASIL}

\section{Karakteristik Responden}

Karakteristik responden yang diteliti menunjukkan bahwa makanan lunak diberikan pada berbagai variasi karakteristik responden, disajikan pada Tabel 1. Dari data yang diperoleh dapat dilihat bahwa responden lebih banyak laki-laki, sebagian besar berusia kurang dari 50 tahun, pendidikan lebih dari 9 tahun, bekerja, nafsu makan tidak terganggu dan pengetahuannya baik.

\section{Daya Terima Makanan Lunak}

Hampir pada setiap waktu makan ditemukan responden yang tidak menghabiskan makanan yang dihidangkan dengan sisa makanan melebihi standar yang ditetapkan Kementerian Kesehatan yaitu maksimal 20 persen (Tabel 2). 
Tabel 1

Distribusi Frekuensi Responden berdasarkan Karakteristik

\begin{tabular}{lcc}
\hline Karakteristik sampel & $\mathrm{n}$ & $\%$ \\
\hline Jenis kelamin & & \\
$\quad$ Perempuan & 33 & 36.7 \\
Laki-laki & 57 & 63.3 \\
\hline Umur & & \\
$\quad<50$ thn & 62 & 68.9 \\
$\quad \geq 50$ thn & 28 & 31.1 \\
\hline Pendidikan & & \\
$\leq 9$ thn & 19 & 21.1 \\
$\quad>9$ thn & 61 & 78.9 \\
\hline Pekerjaan & & \\
Bekerja & 53 & 58.9 \\
$\quad$ Tidak bekerja & 37 & 41.1 \\
\hline Nafsu makan & & \\
Terganggu & 34 & 62.8 \\
$\quad$ Tidak terganggu & 56 & 24.4 \\
\hline Pengetahuan & & 75.6 \\
$\quad$ Kurang & 22 & \\
Baik & 68 &
\end{tabular}

Tabel 2

Distribusi Responden berdasarkan Daya Terima Makanan untuk setiap Waktu Makan

\begin{tabular}{|c|c|c|c|c|c|c|}
\hline \multirow[b]{2}{*}{$\begin{array}{l}\text { Jenis dan Waktu } \\
\text { Makan }\end{array}$} & \multicolumn{2}{|c|}{ Habis } & \multicolumn{2}{|c|}{ Tidak habis } & \multicolumn{2}{|c|}{ Total } \\
\hline & $\mathrm{n}$ & $\%$ & $\mathrm{n}$ & $\%$ & $\mathrm{n}$ & $\%$ \\
\hline \multicolumn{7}{|l|}{ Makanan Pokok } \\
\hline Makan pagi & 42 & 46.7 & 48 & 53.3 & 90 & 100 \\
\hline Makan siang & 38 & 42.2 & 52 & 57.8 & 90 & 100 \\
\hline Makan malam & 46 & 51,1 & 44 & 48.9 & 90 & 100 \\
\hline \multicolumn{7}{|l|}{ Lauk hewani } \\
\hline Makan pagi & 33 & 54 & 28 & 45.9 & 61 & 100 \\
\hline Makan siang & 55 & 61.1 & 35 & 38.9 & 90 & 100 \\
\hline Makan malam & 56 & 62.2 & 33 & 37.0 & 89 & 100 \\
\hline \multicolumn{7}{|l|}{ Lauk nabati } \\
\hline Makan siang & 42 & 47.7 & 46 & 52.2 & 88 & 100 \\
\hline Makan malam & 43 & 51.8 & 40 & 48.1 & 83 & 100 \\
\hline \multicolumn{7}{|l|}{ Sayuran } \\
\hline Makan pagi & 14 & 56 & 11 & 44 & 25 & 100 \\
\hline Makan siang & 44 & 48.9 & 46 & 51.1 & 90 & 100 \\
\hline Makan malam & 44 & 48.9 & 46 & 51.1 & 90 & 100 \\
\hline \multicolumn{7}{|l|}{ Buah } \\
\hline Makan siang & 62 & 71.2 & 28 & 31.1 & 90 & 100 \\
\hline Makan malam & 71 & 80.7 & 19 & 21.1 & 90 & 100 \\
\hline \multicolumn{7}{|l|}{ Makanan selingan } \\
\hline Selingan pagi & 64 & 74.4 & 22 & 25.6 & 86 & 100 \\
\hline Selingan sore & 45 & 75.0 & 15 & 25.0 & 60 & 100 \\
\hline
\end{tabular}


Dilihat dari tabel di atas di setiap waktu makan terdapat lebih dari 40 persen responden menyisakan makanannya di atas standar Kemenkes RI (> 20\%) untuk hidangan makanan pokok, lauk hewani, lauk nabati dan sayuran. Untuk buah dan makanan selingan jumlah yang tidak menghabiskan lebih sedikit.

\section{Alasan responden tidak menghabiskan makanan}

Responden diminta mengemukakan 1 sampai dengan 3 alasan tidak menghabiskan makanan yang disajikan (Tabel 3 ).

Tabel 3

Distribusi Alasan Responden Tidak Menghabiskan Makanan

\begin{tabular}{|c|c|c|c|c|c|}
\hline & \multicolumn{5}{|c|}{ Alasan Responden Tidak Menghabiskan Makanan } \\
\hline & $\begin{array}{l}\text { Terlalu } \\
\text { banyak }\end{array}$ & $\begin{array}{l}\text { Rasa kurang } \\
\text { enak }\end{array}$ & Kenyang & Malas makan & Lainnya \\
\hline \multicolumn{6}{|l|}{ Makanan Pokok } \\
\hline $\begin{array}{l}\text { Makan pagi } \\
\text { (48 responden) }\end{array}$ & $28(58.3 \%)$ & $5(27.8 \%)$ & $24(50 \%)$ & $14(29.1 \%)$ & - \\
\hline $\begin{array}{l}\text { Makan siang } \\
\text { (52 responden) }\end{array}$ & $32(61.5 \%)$ & - & $31(59.6 \%)$ & $23(44.2 \%)$ & - \\
\hline $\begin{array}{l}\text { Makanmalam } \\
\text { (44 responden) }\end{array}$ & $26(59 \%)$ & - & $25(56.8 \%)$ & $18(40.9 \%)$ & - \\
\hline \multicolumn{6}{|l|}{ Lauk hewani } \\
\hline $\begin{array}{l}\text { Makan pagi } \\
\text { (28 responden) }\end{array}$ & - & $20(71.4 \%)$ & $9(32.1 \%)$ & $8(28.6 \%)$ & - \\
\hline $\begin{array}{l}\text { Makan siang } \\
\text { ( } 35 \text { responden) }\end{array}$ & - & $20(57.1 \%)$ & $11(31.4 \%)$ & $16(45.7 \%)$ & - \\
\hline $\begin{array}{l}\text { Makan malam } \\
\text { ( } 33 \text { responden) }\end{array}$ & $\cdot$ & $14(42.4 \%)$ & $13(39.3 \%)$ & $14(42.4 \%)$ & - \\
\hline \multicolumn{6}{|l|}{ Lauk nabati } \\
\hline $\begin{array}{l}\text { Makan siang } \\
\text { ( } 46 \text { responden) }\end{array}$ & - & $15(32.6 \%)$ & $24(52.1 \%)$ & $25(54.3 \%)$ & - \\
\hline $\begin{array}{l}\text { Makan malam } \\
\text { ( } 40 \text { responden) }\end{array}$ & - & $17(42.5 \%)$ & $15(37.5) \%$ & $22(55 \%)$ & \\
\hline \multicolumn{6}{|l|}{ Sayuran } \\
\hline $\begin{array}{l}\text { Makan pagi } \\
\text { ( } 11 \text { responden) }\end{array}$ & - & $8(72.7 \%)$ & $5(45.5 \%)$ & - & - \\
\hline $\begin{array}{l}\text { Makan siang } \\
\text { ( } 45 \text { responden) }\end{array}$ & - & $21(46.7 \%)$ & $23(51.1 \%)$ & $13(28.9 \%)$ & - \\
\hline $\begin{array}{l}\text { Makan malam } \\
\text { (45responden) }\end{array}$ & - & $28(15.5 \%)$ & $16(26.7 \%)$ & $13(28.9 \%)$ & - \\
\hline \multicolumn{6}{|l|}{ Buah } \\
\hline $\begin{array}{l}\text { Makan siang } \\
\text { (25 responden) }\end{array}$ & $4(16 \%)$ & $12(48 \%)$ & - & $14(56 \%)$ & $\begin{array}{l}7(28 \%) \text { tdk } \\
\text { sesuai diet }\end{array}$ \\
\hline $\begin{array}{l}\text { Makan malam } \\
\text { ( } 17 \text { responden) }\end{array}$ & - & $10(58.8 \%)$ & $4(23.5 \%)$ & $10(58.8 \%)$ & \\
\hline \multicolumn{6}{|l|}{ Makanan selingan } \\
\hline pagi (22 responden) & - & $15(68.2 \%)$ & $8(36.3 \%)$ & $5(22.7 \%)$ & - \\
\hline Sore(15 responden) & - & $10(66.7 \%)$ & $6(40 \%)$ & $9(60 \%)$ & - \\
\hline
\end{tabular}

Dari Tabel 3 dapat dilihat bahwa sebagian besar responden mengemukakan alasan tidak menghabiskan makanan pokok disebabkan karena porsi yang diberikan terlalu besar. Untuk 
lauk hewani, sayuran, dan makanan selingan sebagian besar alasan responden tidak menghabiskan makanan adalah rasa kurang enak. Untuk lauk nabati dan buah sebagian besar responden yang tidak menghabiskan mengatakan malas makan hidangan yang disajikan.

\section{Hidangan yang tidak disukai responden}

Beberapa hidangan tidak disukai responden, sehingga tidak dimakan atau tidak dihabiskan. Makanan yang tidak disukai responden untuk masing-masing rumah sakit disajikan pada Tabel 4.

Tabel 4

Hidangan yang Tidak Disukai Responden

\begin{tabular}{|c|c|c|c|}
\hline \multirow{2}{*}{ Waktu makan } & \multicolumn{3}{|c|}{ Hidangan yang tidak disukai responden Berdasar Rumah Sakit } \\
\hline & RS Pasar Rebo & RS I Sukapura & RS Persahabatan \\
\hline \multicolumn{4}{|l|}{ Lauk Hewani } \\
\hline Makan pagi & - & Telur rebus & Telur rebus \\
\hline Makan siang & $\begin{array}{l}\text { Ayam panggang } \\
\text { kecap }\end{array}$ & $\begin{array}{l}\text { Tuna panggang } \\
\text { bumbu gulai }\end{array}$ & - \\
\hline Makan malam & $\begin{array}{l}\text { Ikan tenggiri } \\
\text { bumbu saos tomat }\end{array}$ & - & - \\
\hline \multirow{3}{*}{$\begin{array}{l}\text { Lauk nabati } \\
\text { Makan siang } \\
\text { Makan malam }\end{array}$} & & & \\
\hline & Tempe bacem & Gadon tahu & Tumis tempe \\
\hline & Oseng tempe & $\begin{array}{l}\text { Makaroni lapis, } \\
\text { oseng makaroni, } \\
\text { pastel kentang }\end{array}$ & Gadon tahu \\
\hline \multirow{2}{*}{$\begin{array}{l}\text { Sayuran } \\
\text { Makan pagi }\end{array}$} & & & \\
\hline & Sop makaroni & - & - \\
\hline Makan siang & - & $\begin{array}{l}\text { Sayur lodeh dan } \\
\text { tumis kacang } \\
\text { panjang }\end{array}$ & Oseng buncis \\
\hline Makan malam & Bening labu siam & Bobor bayam & - \\
\hline
\end{tabular}

Dari tabel di atas dapat dilihat untuk setiap rumah sakit ada hidangan yang tidak disukai responden baik untuk lauk hewani, lauk nabati dan sayuran. RSI Sukapura paling banyak mempunyai makanan yang tidak disukai sedangkan RS Persabatan yang paling sedikit mempunyai hidangan tidak disukai reponden.

Penilaian variasi menu, penampilan makanan, dan paduan rasa makanan

Responden memberikan penilaian terhadapvariasi menu, penampilan makanan, dan paduan rasa makanan. Hasil penilaian responden terhadap variasi menu sebanyak 63,7 persen menilai pada level 6-7 dan sebanyak 31,4 persen menilai pada skore $\geq 8$. Adapun penilaian terhadap penampilan makanan, 62,6 persen responden menilai pada level 6-7 dan sebanyak 31,8 persen menilai pada skore $\geq 8$. Penilaian terhadap paduan rasa makanan, sebanyak 59,6 persen responden menilai pada level 6-7 dan 29,2 persen responden memberikan penilaian $\geq 8$ (Tabel 5). 
Tabel 5

Penilaian variasi menu, penampilan makanan, dan paduan rasa makanan

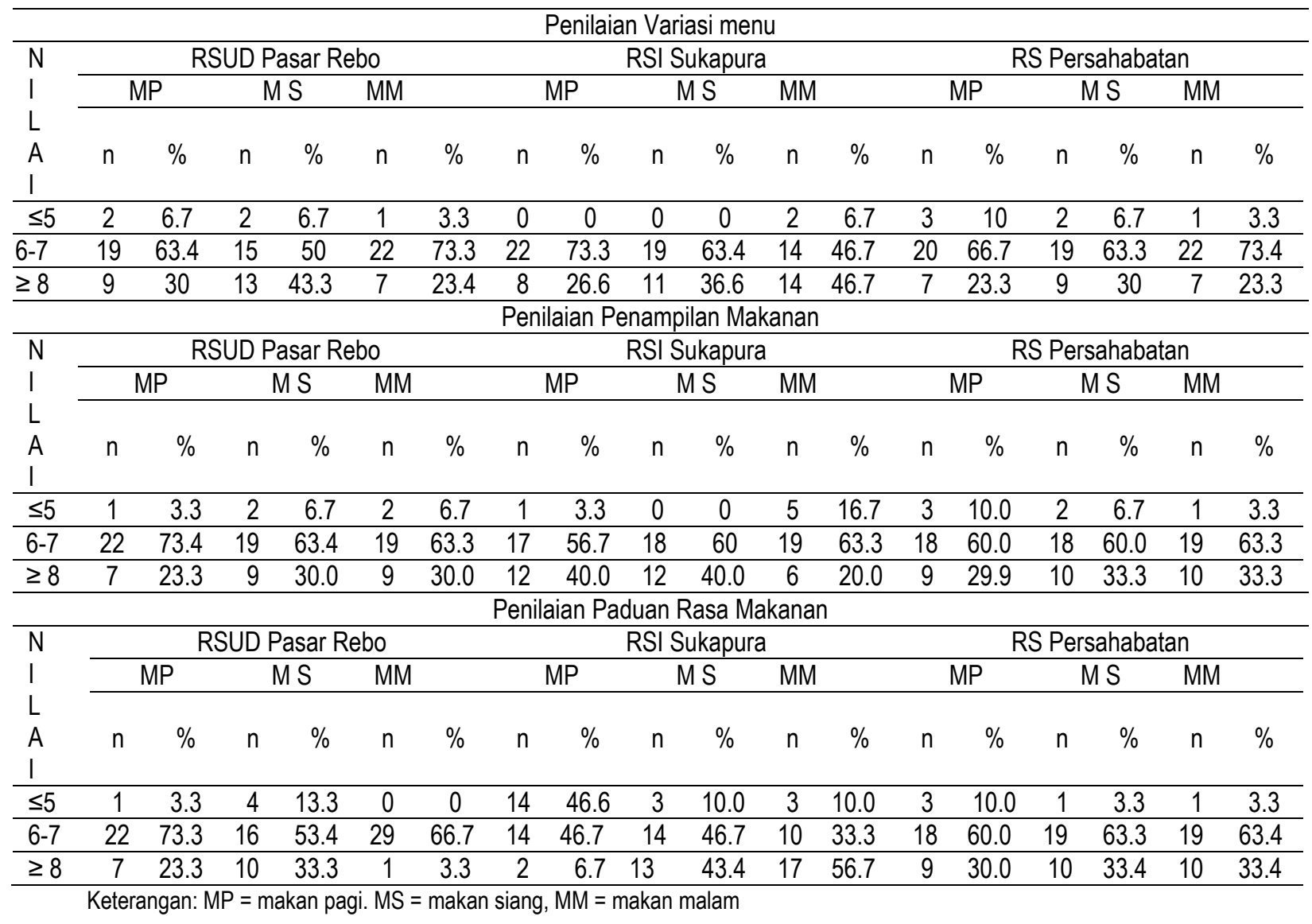

Responden yang memberi penilaian $\geq 8$ untuk aspek variasi menu, penampilan makanan dan paduan rasa makanan.lebih banyak dibanding yang memberi penilaian $<5$. Namun jumlah responden terbanyak adalah yang yang memberi penilaian antara $6-7$.

\section{Sistem Penyelenggaraan Makanan Lunak}

Penilaian tentang penyelenggaraan makanan lunak dilakukan dengan penilaian persepsi terhadap makanan lunak. (Tabel 6).

Tabel 6

Penilaian Sistem Penyelenggaraan Makanan Lunak

\begin{tabular}{lcccccc}
\hline \multirow{2}{*}{ Hal yang dinilai } & \multicolumn{2}{c}{ RSUD Ps Rebo } & \multicolumn{2}{c}{ RSI Sukapura } & \multicolumn{2}{c}{ RS Persahabatan } \\
\cline { 2 - 7 } & Baik & Kurang & Baik & Kurang & Baik & Kurang \\
\hline $\begin{array}{l}\text { Pergantian menu: baik bila dilakukan1-2x } \\
\text { setahun. Kurang baik bila }>2 \text { tahun } \\
\text { sekali }\end{array}$ & $\sqrt{ }$ & & $\sqrt{ }$ & & $\sqrt{ }$ \\
\hline $\begin{array}{l}\text { Siklus menu: Baik bila ada dan ditaati, } \\
\text { kurang baik bila tidak ada atau tidak } \\
\text { ditaati }\end{array}$ & $\sqrt{ }$ & & & & & \\
\hline $\begin{array}{l}\text { Variasi menu: Baik bila dalam satu set } \\
\text { menu, rasa, warna, konsistensi, bahan } \\
\text { makanan bervariasi. Kurang baik bila }\end{array}$ & $\sqrt{ }$ & & & & & \\
\hline
\end{tabular}


dalam 1 set menu, rasa, warna, konsistensi, tekstur makanan bervariasi kurang bervariasi.

Standar resep: Baik bila ada dan digunakan, kurang bila ada/ tidak ada dan tidak digunakan

Besar porsi hidangan: Baik bila sesuai dengan nilai gizi yang ditetapkan rumah sakit dan dapat dihabiskan pasien, kurang baik bila tidak sesuai atau tidak dapat dihabiskan

Waktu penyajian: Baik bila disajikan tepat sesuai SOP, kurang baik bila tidak tepat

Alat transportasi: alat angkut makanan keruangan, Baik bila memenuhi syarat sanitasi, kurang baik bila belum memenuhi syarat sanitasi.

Alat saji: Baik bila disenangi responden, kurang baik bila tidak disenangi responden

Pencucian dan penyimpanan alat makan: Baik bila sesuai standar pencucian alat, kurang baik bila belum sesuai standar

Hygiene penjamah makanan (distribusi): Baik bila sudah sesuai standar, belum baik bila belum sesuai standar

Dari 10 aspek yang dinilai, di RS Pasar Rebo ada 6 aspek yang mendapat penilaian baik, RSI Sukapura ada 4 aspek, sedangkan RS Persabatan ada 3 aspek. Untuk aspek standar resep, besar porsi hidangan dan hygiene penjamah makanan tidak ada rumah sakit yang dinilai baik.

\section{BAHASAN}

\section{Karakteristik Responden}

Karakteristik responden sebagian besar adalah laki-laki, lebih banyak yang berusia di bawah 50 tahun, sebagian besar melewati pendidikan dasar 9 tahun. Lebih banyak responden yang bekerja, tidak terganggu selera makannya dan mempunyai pengetahuan baik tentang makanan lunak. Ada perbedaan dengan penelitian Harvie dimana perempuan lebih banyak dari laki-laki, namun pada kedua penelitian umur lebih banyak dibawah 50 tahun. ${ }^{5}$ Almatsier (1992) mengemukakan bahwa sisa makanan dipengaruhi oleh beberapa faktor yaitu jenis kelamin, tingkat pendidikan, kelompok umur, citarasa makanan, kelas perawatan, lama perawatan dan penyakit. ${ }^{6}$

\section{Daya Terima Makanan Lunak}

Makanan pokok tidak dihabiskan oleh separuh responden, hal ini hampir sama dengan penelitian yang dillakukan Eliya (2003) yang menunjukkan bahwa rata-rata dalam sehari 57,3 persen responden tidak menghabiskan makanan pokoknya. ${ }^{7}$ Menurut penelitian Harvie (2011) rata-rata 81,8 persen responden tidak menghabiskan makanan pokok yang dihidangkan. ${ }^{5}$

Untuk lauk hewani sebagian responden tidak mendapatkan lauk hewani pada waktu makan pagi dan makan malam dikarenakan pembatasan jumlah protein berdasarkan jenis diet dari masing-masing responden. Dilihat dari Tabel 2 persentase responden yang tidak menghabiskan lauk hewani pada setiap waktu 
makan cukup besar yaitu di atas 35 persen. Hampir sama dengan penelitian Eliya rata-rata dalam sehari 38,5 persen responden tidak menghabiskan lauk hewani yang dihidangkan. ${ }^{7}$ Penelitian Harvie menunjukkan bahwa 33 persen responden tidak menghabiskan hidangan telur yang disajikan dan penelitian Murni (2012) menunjukkan 57,1 persen responden tidak menghabiskan hidangan telur yang disajikan. ${ }^{5,8}$

Pada waktu makan pagi semua responden tidak mendapat lauk nabati, pada waktu makan siang 2 orang dan makan malam 7 orang tidak diberi lauk nabati karena alasan diet. Responden yang tidak menghabiskan lauk nabati setiap waktu makan rata-rata lebih dari 40 persen, lebih kecil dibanding penelitian Eliya rata-rata/hari 50 persen responden tidak menghabiskan lauk nabati. ${ }^{7}$ Sedangkan penelitian Harvie rata-rata/hari 40,9 persen responden tidak menghabiskan lauk nabati. ${ }^{5}$

Lebih dari 50 persen responden tidak menghabiskan sayuran yang disajikan waktu makan siang dan makan malam. Hal ini menunjukkan bahwa pada hidangan sayuran masih ada masalah. Pada makan pagi, RS Islam Sukapura dan RS Persahabatan tidak menyajikan sayuran.Namun sisa sayuran ratarata sehari hampir sama dengan penelitian Eliya (65.6\%) dan penelitian Harvie (72,7\%). 5,7

Secara keseluruhan daya terima buah cukup baik, yaitu yang tidak menghabiskan hanya dibawah 30 persen. Penelitian Elya juga menunjukkan rata-rata/hari 29,7 persen responden tidak menghabiskan hidangan buah. ${ }^{7}$

Dalam penelitian ini tidak ada rumah sakit yang memberikan makanan selingan malam, dan untuk RS persahabatan pasien tidak diberikan makanan selingan sore. Berdasarkan Tabel $2 \mathrm{di}$ atas persentase yang tidak menghabiskan makanan selingan pagi dan selingan sore masih ada 25 persen lebih responden. Hal ini sama dengan penelitian Harvie ( 27,3\%) namun berbeda dengan penelitian Eliya (50\%), 5,7 Aroni (2011) menyimpulkan bahwa tidak terdapat hubungan yang bermakna antara kualitas makanan dengan daya terima pasien terhadap makanan lunak tanpa diet. ${ }^{4} \mathrm{Hal}$ ini menunjukkan bahwa menunjukkan bahwa daya terima pasien tidak hanya dipengaruhi oleh kualitas makanan. Menurut Moehyi (1995) manifestasi depresi menyebabkan rendahnya konsumsi makanan lunak dari menu yang disediakan rumah sakit. ${ }^{9}$

\section{Alasan responden tidak menghabiskan makanan}

Alasan terbanyak makanan pokok tidak dihabiskan adalah porsi yang terlalu besar, kenyang, dan malas makan. Responden yang mengatakan kenyang ternyata juga mengkonsumsi makanan selain yang diberikan rumah sakit. Rasa mual dialami pasien terutama pada hidangan bubur sumsum ditambah telur rebus (RSI Sukapura), bubur yang diberi kuah santan (RS Persahabatan) disarankan untuk diganti kuah kaldu. Juga responden menginginkan bubur diganti dengan nasi lembik, karena bubur membuat mual. Keluhan responden di RS Pasar Rebo adalah alat makan sterofoam yang dirasakan mengganggu selera makan pasien sebaiknya tidak digunakan sebagai alat saji.

Keluhan dari responden yang malas makan lauk hewani adalah rasa makanan yang kurang bumbu (RS Pasar Rebo), tidak sesuai selera (RSI Sukapura), kurang matang dan terlalu asin (RS Persahabatan). Dalam hal ini standar resep menjadi hal yang sangat penting. Penelitian Elya 21,9 persen responden menyatakan lauk hewani tidak enak. ${ }^{7}$ Sedangkan hasil penelitian Murni menunjukkan 50 persen responden mengatakan hidangan telur tidak enak. ${ }^{8}$

Responden yang tidak menghabiskan lauk nabati karena tidak menyukai rasa dan penampilan makanannya. Keluhan yang disampaikan responden adalah lauk nabati rasanya hambar kurang bumbu dan hidangan nabati kurang bervariasi. Untuk itu diperlukan konseling gizi untuk memberi pengetahuan kepada pasien tentang gizi seimbang dan perbaikan citarasa lauk nabati. Penelian Elya menunjukkan 25 persen responden tidak menyukai citarasa sayuran. ${ }^{7}$ Hasil tabulasi silang ternyata responden yang tidak menghabiskan lauk nabati juga mempunyai keluhan mual, demam, dan gangguan selera makan. Hasil penelitian Kolodinsky (2007) mengatakan bahwa konsumsi buah, susu, protein dan kacang-kacangan dapat ditingkatkan dengan menambah pengetahuan tentang "dietary guidance". ${ }^{10}$ Berarti konseling tentang makanan lunak perlu di tingkatkan untuk menambah pengetahuan pasien. 
Dari hasil tabulasi silang antara keluhan dengan daya terima sayuran di masing-masing waktu makan dapat dilihat bahwa responden yang mengeluh mual tidak dapat menghabiskan sayuran yang dihidangkan. Jika dilihat dari menu yang terdiri dari bubur ayam atau bubur sumsum maka perlu dipikirkan jenis masakan sayur yang sesuai. Hal ini sejalan dengan penelitaian Elya yaitu 40,6 persen responden mengatakan citarasa sayuran tidak enak. ${ }^{7}$

Hidangan buah disajikan dengan tujuan untuk mencukupi kebutuhan serat dan zat gizi mikro pasien, dan juga sebagai penyegar setelah makan. Bila dilihat dari tabulasi silang responden yang mempunyai pengetahuan baik lebih banyak menghabiskan hidangan penutup. Masih adanya responden yang tidak menghabiskan buah adalah disebabkan rasa buah yang dihidangkan tidak manis, bahkan jeruk sering asam serta buah potong dirasakan kurang bersih. Hal ini berbeda dengan penelitian Elya dimana hanya 3,1 persen responden yang mengatakan citarasa hidangan penutup tidak enak. ${ }^{7}$

Sebagian responden menyarankan agar porsi makanan pokok dikurangi dan diganti dengan makanan selingan. Rasa pada makanan selingan menjadi sesuatu yang sangat penting dalam pengolahan makanan di rumah sakit. Asupan gizi dapat meningkat dengan pemberian makanan selingan yang porsinya kecil namun memiliki energi tinggi. Data yang diperoleh dalam penelitian ini hampir sama dengan penelitian Elya yaitu responden tidak menghabiskan makanan karena tidak selera makan 30,8 persen, tidak suka 15,4 persen, kenyang 15,4 persen dan rasa tidak enak 23 persen. ${ }^{7}$ Ariefuddin (2007) membuktikan ada hubungan bermakna antara jenis kelamin, tingkat pendidikan, jenis penyakit dan selera makan dengan terjadinya sisa makanan lunak, sedangkan menurut umur tidak ada hubungan bermakna. ${ }^{11} \mathrm{Hal}$ ini berbeda dengan penelitian Almatsier (1992) bahwa umur pasien berhubungan dengan asupan makanan pasien. ${ }^{6}$ Umur pasien 41-90 tahun mempunyai kemungkinan 0.4 kali lebih kecil dalam asupan makanan pasien rawat inap dibanding umur pasien 15-40 tahun

\section{Hidangan yang tidak disukai responden}

Responden menyarankan agar masakan yang tidak disukai dapat diperbaiki atau tidak disajikan lagi, terutama untuk lauk hewani agar berupa menu pilihan yang ditawarkan pada pasien. Beberapa masakan yang kurang disukai responden dan juga tidak dapat menggantikan peran lauk nabati adalah pengganti lauk nabati dari karbohidrat seperti oseng makaroni dan perkedel kentang bakar. Untuk mengatasinya dapat dilakukan dengan mencampur sumber bahan makanan sumber protein nabati seperti kacang-kacangan. Responden yang mengatakan tidak suka mengemukakan alasan masakan protein nabati kurang berbumbu, sehingga menimbulkan rasa mual dan kurang bervariasi sehingga bosan. Untuk itu perlu dilakukan evaluasi resep-resep nabati dan lebih berkreasi dengan resep masakan agar menu lebih bervariasi dan disukai semua pasien

Beberapa responden menginginkan sayuran dimasak berkuah, lebih bervariasi dan berbumbu. Tekstur sayuran yang masih keras juga menjadi keluhan responden. Sayuran yang dihidangkan dalam sterofoam menurunkan selera makan. Penelitian yang dilakukan oleh Napoleone (2007) menyatakan bahwa konsumsi sayuran dapat ditingkatkan dengan mengurangi/ menghilangkan rasa getir/ pahit pada sayuran dan meningkatkan rasa manis sayuran. ${ }^{12}$

Hidangan buah yang disajikan berupa jeruk, melon, pepaya, semangka,dan pisang. Namun banyak responden yang belum mengetahui buah apa saja yang sesuai untuk makanan lunak. Pemberian konseling akan sangat membantu daya terima pasien terhadap buah, agar tidak terbuang dan kebutuhan zat gizi mikro dapat terpenuhi. Beberapa responden mengatakan jeruk yang diberikan tidak sesuai diet karena rasanya asam. Responden lain mengatakan pemilihan buah dan penyajiannya kurang bervariasi. Cara menyajikan buah potong dirasakan kurang bersih karena dalam keadaan terbuka.

Masih ada makanan selingan yang tidak dimakan disebabkan citarasa yang tidak disukai responden. Meskipun rasa merupakan hal relatif yang lebih bersifat indiviual namun pada makanan selingan perlu dikaji ulang agar semua responden menyukainya dan makanan selingan tidak terbuang percuma. Untuk itu perlu kreasi resep dan sebaiknya makanan selingan pun diberikan di tiga waktu makan karena bisa sebagai solusi untuk memenuhi kebutuhan zat gizi pasien yang belum terpenuhi 
dari hidangan utama. Ariefuddin (2007) mengatakan rata-rata pasien rawat inap memperoleh makanan lunak sekitar 40,1 persen dan sekitar 20,5 persen meninggalkan sisa makanannya. ${ }^{11}$

\section{Penilaian variasi menu, penampilan makanan, dan paduan rasa makanan}

Variasi menu masih memerlukan perbaikan. Hal ini dapat dilihat dari hidangan lauk hewani pada makan pagi yang tidak bervariasi hampir tiap hari disajikan telur rebus, hidangan nabati sebagian besar berbahan dasar tempe dan tahu saja belum menggunakan kacang-kacangan, hidangan sayuran kebanyakan disajikan dalam bentuk sayur bening.

Penampilan makanan yang menarik akan membantu pasien menghabiskan makanan yang disajikan. Ketidak seimbangan antara variasi warna masakan, konsistensi, dan bentuk/potongan bahan makanan menyebabkan penampilan makanan terlihat tidak menarik. Dari hasil penelitian penampilan makanan yang disajikan masih perlu ditingkatkan dengan pemberian garnish, kombinasi warna masakan dan penggunaan bumbu untuk meningkatkan warna dan aroma makanan. Juga penggunaan alat saji sangat mempengaruhi penampilan makanan

Rasa makanan sangat ditentukan oleh penggunaan bumbu dan teknik pemasakan. Untuk paduan rasa makanan yang sangat penting diperhatikan adalah perpaduan antara variasi jenis masakan yang dihidangkan dalam waktu yang sama agar menjadi paduan makanan yang enak. Dengan menurunnya kepekaan indera pengecap pasien dibandingkan orang yang sehat maka ketrampilan menggunakan bumbu masakan dan teknik memasak perlu lebih ditingkatkan. Penelitian Elya responden yang mengatakan kurang variasi untuk lauk hewani sebesar 25 persen, lauk nabati 21,9 persen, sayuran 34,4 persen, buah 18,7 persen dan makanan selingan 12,5 persen. ${ }^{7}$ Hasil penelitian Murni 27,3 persen responden mengatakan penampilan hidangan telur tidak menarik. ${ }^{8} \mathrm{Hal}$ yang hampir sama dari hasil penelitian Harvie adalah 22,9 persen yang mengatakan citarasa makanan kurang baik. ${ }^{5}$ Namun penelitian Ariefuddin (2007) menunjukkan tidak ada hubungan bermakna antara kepuasan responden mengenai mutu makanan dengan sisa makanan. ${ }^{11}$

\section{Sistem Penyelenggaraan Makanan Lunak}

Pergantian menu: RSUD Pasar Rebo dinilai baik karena pergantian menu dilakukan 6 bulan sekali, hal ini memungkinkan untuk mengganti hidangan yang tidak disukai pasien dan menambahkan usulan hidangan yang disukai pasien kedalam menu. Berbeda dengan dua rumah sakit lainnya dimana keinginan pasien tidak dapat langsung diantisipasi.

Siklus menu: Ketiga rumah sakit menggunakan siklus menu 10 hari dan dipakai untuk penyelenggaraan makanan lunak. Selama penelitian hidangan yang disajikan sama dengan menu yang sudah direncanakan.

Variasi menu: Dalam penelitian ini masih banyak hidangan yang kurang bervariasi. Khusus untuk hidangan lauk nabati hendaknya tidak diganti dengan bahan makanan sumber karbohidrat, atau dikombinasi dengan lauk nabati dengan proporsi lauk nabati lebih besar. Variasi menu dapat dilakukan dengan menambah standar resep, yang dibukukan berdasarkan klasifikasi resep. Hal ini akan membantu pada waktu penyusunan menu dan memperkaya variasi menu, baik dari rasa, warna, konsistensi, penggunaan bahan makanan dan teknik pemasakan.

Standar resep: Standar resep merupakan hal yang penting dalam suatu penyelenggaraan makanan banyak. Umumnya penyelenggaraan makanan komersial menggunakan standar resep sehingga mudah untuk mengawasi citarasa dan harga makanan. Dalam penelitian ini ketiga rumah sakit belum belum menggunakan standar resep dalam produksi makanan sehari-hari.

Besar porsi hidangan: Dari hasil pengamatan besar porsi hidangan di ketiga rumah sakit sudah sesuai dengan yang ditetapkan rumah sakit. Namun demikian besar porsi belum mengantisipasi kemampuan pasien menghabiskan hidangan yang disajikan, sehingga makanan yang disajikan banyak yang terbuang. Sedangkan porsi buah dan makanan selingan masih dirasakan kurang. Ariefuddin (2007) membuktikan bahwa ada hubungan antara ketidaksesuaian terhadap standar porsi makanan lunak rumah sakit dengan sisa makanan terutama makanan pokok, lauk hewani, lauk nabati dan sayur. ${ }^{11}$ 
Waktu penyajian: Dari hasil pengamatan penyajian makanan di ketiga rumah sakit selalu tepat waktu. Sehingga dapat dikatagorikan baik

Alat transportasi: Alat angkut makanan keruangan umumnya menggunakan troli. Kebersihan troli perlu dijaga, apabila troli yang digunakan merupakan troli tertutup kebersihan di bagian dalam perlu mendapat perhatian, sedangkan yang menggunakan troli terbuka alat hidang yang digunakan sudah dalam keadaan tertutup. Dalam penelitian ini ketiga rumah sakit sudah menggunakan alat angkut yang cukup baik.

Alat saji: Dari hasil penelitian diketahui bahwa sebagian besar responden di RSUD Pasar Rebo mengeluhkan penggunaan sterofoam sebagai alat saji. Sedangkan didua rumah sakit lainnya alat saji tidak menjadi masalah. Alat saji yang baik dapat meningkatkan selera makan pasien.

Pencucian dan penyimpanan alat makan: Pencucian alat hendaknya melalui 4 tahapan yaitu penetrasi, suspensi, pembilasan, dan sanitasi. Tahapan ini belum sepenuhnya dilakukan di tiga rumah sakit.

Hygiene penjamah makanan (distribusi): Petugas distribusi makanan sudah mengenakan pakaian yang bersih. Namun belum dilengkapi dengan celemek dan tutup kepala. Penggunaan celemek dan tutup kepala untuk menjaga kebersihan makanan

Penelitian yang dilakukan oleh Carrier (2007) membuktikan bahwa siklus menu, modifikasi resep, alat saji dan kemasan serta cara distribusi makanan berhubungan bermakna dengan kejadian malnutrisi karena mengurangi asupan makanan. ${ }^{13}$

\section{SIMPULAN DAN SARAN}

\section{Simpulan}

Sebagian besar responden belum menghabiskan makanan lunak yang disajikan dengan alasan porsi terlalu banyak, rasa kurang enak, kenyang, malas makan dan merasa tidak sesuai dengan dietnya. Baru 31.8 persen responden memberikan penilaian baik terhadap variasi menu, penampilan makanan, dan paduan rasa makanan yang disajikan. Masih ada masalah dalam sistem penyelenggaraan makanan lunak tentang menu, standar resep, besar porsi, alat saji, hygiene dan sanitasi.

\section{Saran}

Perlu dilakukan perbaikan menu makanan lunak berdasarkan evaluasi menu dengan memperhatikan selera pasien, serta membakukan resep masakan dalam standar resep. Untuk mengantisipasi sisa makanan dapat dilakukan pengurangan besar porsi hidangan utama dan dialihkan ke makanan selingan, penggunaan alat saji yang layak, melengkapi petugas distribusi makanan dengan celemek dan topi, meningkatkan pengetahuan responden tentang makanan lunak melalui konseling.

\section{RUJUKAN}

1. Direktorat Bina Pelayanan Medik dasar, Dirjen Bina pelayanan Medik, Pedoman Penyelenggaraan Makanan Rumah Sakit, DepKes RI, 2007

2. Departemen Kesehatan Republik Indonesia. Pedoman pelayanan Gizi Rumah Sakit, Jakarta 2003.

3. Instalasi Gizi RSCM dan Asosiasi Dietisien Indonesia, Penuntun Diet, Jakarta, 2008

4. Aroni, Hasan Hubungan Kualitas Makanan Lunak dengan Daya Terima Pasien Rawat Inap Kelas III di Rumah Sakit. Malang Nutrition Research, 2010.

5. Harvie, Nabilah Khairani. Sisa makakan lunak ditinjau dari citarasa makanan rumah sakit dan konsumsi makanan dari luar pada pasien rawat inap kelas III di RSUD Budhi Asih Jakarta Timur, tahun 2011. Karya Tulis IImiah Jurusan Gizi Poltekkes Jakarta II, 2011

6. Almatsier, S. Persepsi pasien terhadap makanan di rumah sakit. Gizi Indonesia, vol 17 hal 87-96, Jakarta.1992

7. Eliya, Tati. Gambaran sisa konsumsi makanan lunak pasien rawat inap ditinjau dari pembagian waktu makan dan jenis makanan serta faktor penyebabnya di RSUD Pasar Rebo Jakarta. Karya Tulis IImiah Jurusan Gizi Poltekkes Jakarta II, 2003

8. Murni, Dewi. Hubungan karakteristik sampel dan citarasa makanan terhadap daya terima telur dalam menu makanan lunak pada pasien di RS Sukmul Medika Jakarta, tahun 2012. Karya Tulis IImiah Jurusan Gizi Poltekkes Jakarta II, 2012 
9. Moehyi, Syahmien, Pengaturan makanan untuk diet dan penyembuhan penyakit. Gramedia Jakarta, 1995

10. Kolodinsky Jane et al. Knowledge of current dietary guidelines and food choice by college students: Better eats have higher knowledge of Dietary Guidance. Jounal of the American Dietetics Association, Agustus 2007: 1409-1413

11. Ariefuddin, Muhammad Agus. Analisis sisa makanan lunak rumah sakit pada penyelenggaraan makanan dengan sistem Outsourcing di RSUD Gunung Jati Kota Cirebon. Program Studi S2 IImu Kesehatan
Masyarakat (Gizi dan Kesehatan) UGM, 2007

12. G Napoleone, C. Conliffe, J.E Hayes, K. Kneeland. Modifying vegetables taste to improve liking. Jounal of the American Dietetics Association, Agustus 2007, supplement 3 abstracts volume 107 number 8: A 76

13. N. Carrier, D. Quellet, G.E West. Foodservice nutritional care and staffing are associated with risk of malnutrition in long term care. Jounal of the American Dietetics Association, Agustus 2007, supplement 3 abstracts volume 107 number 8: A 32 